YEARBOOK

of ANTITRUST

and REGULATORY

STUDIES

www.yars.wz.uw.edu.pl
Peer-reviewed scientific periodical, focusing on legal and economic issues of antitrust and regulation. Creative Commons Attribution-No Derivative Works 3.0 Poland License.

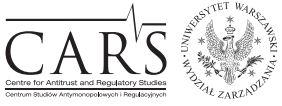

Centre for Antitrust and Regulatory Studies, University of Warsaw, Faculty of Management www.cars.wZ.uw.edu.pl

\title{
Private Antitrust Enforcement Without Punitive Damages: A Half-Baked Reform?
}

\author{
by
}

Claudia Massa*

\section{CONTENTS}

I. Introduction

II. Punitive damages in the case-law

III. The recoverable damage in Directive 2014/104/EU

IV. Some considerations on the exclusion of punitive damages from private antitrust enforcement

$\mathrm{V}$. On the advisability of providing for punitive damages in private antitrust enforcement. A possible solution

VI. Conclusion

\section{Abstract}

Directive 2014/104/EU on private antitrust enforcement opted for the exclusion of punitive damages from the category of recoverable damages following a violation of antitrust law. This article will outline the concept of punitive damages and analyse the relevant case-law of the courts of the Member States, of the ECtHR and of the ECJ. Then, it will examine the regime laid down in the Directive and consider the possible reasons why the European legislator opted for this exclusion. Thus, the opportunity to introduce such a provision into the European legal system will be evaluated, taking into consideration the problem of overdeterrence, the problem of the division of functions between public and private enforcement, and making a comparison with the relevant provisions of Directive 2004/48/EC on the

* LLM in European Law at Panthéon-Assas University (Paris II). Currently Ph.D. Candidate in Economic Law at University of Naples Federico II - Department of Law. An earlier version of this contribution was presented at the First Gaetano Filangieri Conference on Freedom of Commerce 'Recent developments in EU Competition Law', held at the University of Naples 'Federico II' on 8-9 May 2018. Article received: 12 April 2018; accepted: 7 June 2018. 
enforcement of intellectual property rights. Finally, a possible modification of Article 3(3) of the Directive will be suggested, in the framework of the review that the Commission is required to undertake by December 27, 2020.

\section{Résumé}

La Directive 2014/104/UE sur l'application privée du droit de la concurrence a opté pour l'exclusion des dommages-intérêts punitifs de la catégorie des dommages recouvrables suite à la violation du droit de la concurrence. Cet article décrira la notion de dommages-intérêts punitifs et analysera la jurisprudence pertinente des tribunaux des États membres, de la CEDH et de la CJUE. Ensuite, il examinera le régime prévu par la Directive et examinera les raisons possibles pour lesquelles le législateur européen a opté pour cette exclusion. Donc, l'opportunité d'introduire une telle disposition dans le système juridique européen sera d'évaluée en prenant en considération le problème de la dissuasion excessive, celui de la répartition des fonctions entre l'application publique et privée du droit de la concurrence et en faisant une comparaison avec les dispositions pertinentes de la Directive 2004/48/EC relative au respect des droits de propriété intellectuelle. Enfin, une éventuelle modification de l'article 3, paragraphe 3, de la Directive sera d'envisagée, dans le cadre d'une révision de la Directive que la Commission doit faire au plus tard le 27 décembre 2020.

Key words: competition law; private antitrust enforcement; compensation; punitive damages; deterrence

JEL: K21, L40

\section{Introduction}

In the field of competition law, an action for damages deriving from an antitrust violation is an important civil remedy that, firstly, has the function of protecting the rights of individuals. It is debated whether an action for damages must also have a deterrent purpose towards the companies that engage in anti-competitive conduct on the market. Directive 2014/104/EU ${ }^{1}$ (hereinafter, the Damages Directive) arguably leaves this deterrent function to public enforcement. On the other hand, in various jurisdictions, the deterrent function is entrusted to so-called punitive damages, a common law concept of

1 Directive 2014/104/EU of the European Parliament and the Council of 26 November 2014 on certain rules governing actions for damages under national law for infringements of the competition law provisions of the Member States and of the European Union, OJ L 349, 5.12.2014, p. 1-19. 
Anglo-American origin, recognized by the Court of Justice of the European Union $^{2}$, which consists of the award of a further sum of money, in addition to that necessary to compensate the injured party for the harm suffered, as a consequence of the anti-competitive conduct.

After having framed the concept of punitive damages and having analysed the relevant case-law of the courts of the Member States, of the European Court of Human Rights and of the Court of Justice of the European Union, this article examines the regime laid down in the Damages Directive ${ }^{3}$ and discusses the reasons why, when drafting this Directive, the European legislator opted for the exclusion of punitive damages from the category of recoverable damages following a violation of antitrust law.

Subsequently, this article will evaluate the opportunity to introduce such a provision into the European legal system, taking into consideration the problem of overdeterrence and the division of functions between public and private enforcement. Also, a comparison will be made with the relevant provisions of Directive 2004/48/EC on the enforcement of intellectual property rights.

Finally, a possible modification of Article 3, paragraph 3 of the Damages Directive will be suggested, in the framework of the review that the Commission is required to carry out for the submission of a report to the European Parliament and the Council by 27 December 2020, as per Article 20 of the Directive.

\section{Punitive damages in the case-law}

Punitive damages are a typical concept of common law countries and they are used especially in the United Kingdom ${ }^{4}$ (Cappelletti, 2015) (except

2 See Judgment of the European Court of Justice, Joined Cases C-295/04 a C-298/04, Vincenzo Manfredi v Lloyd Adriatico Assicurazioni SpA e altri, EU:C:2006:461; Judgment of the European Court of Justice, Case C-46/93 e C-48/93, Brasserie du Pêcheur SA v. Bundesrepublik Deutschland e The Queen v Secretary of State for Transport, ex parte: Factortame Ltd e altri, EU:C:1996:79; Judgement of the European Court of Justice, case C-367/15, Stowarzyszenie Otawska Telewizja Kablowa, EU:C:2017:36, para 27.

3 Although Article 3, paragraph 3 excludes punitive, multiple and other types of damages, due to space constraints, this chapter will only focus on punitive damages.

4 The first judgement that recognized punitive damages was issued in England in 1763 (Huckle v. Money, [1763] 2 Wils. 205, 95 Eng. Rep. 768 (K.B.)). Later, the concept of punitive damages was transplanted to the United States. In the field of competition law, the first ruling whereby the UK Competition Appeal Tribunal (CAT) awarded punitive damages to the victim of an abuse of a dominant position was issued on 5 July 2012 (case 2 Travel Group Plc v. Cardiff City Transport Services Limited). 
for Scotland ${ }^{5}$ (Fulton, 2017)), in the Republic of Ireland, ${ }^{6}$ in Cyprus, in the United States, and in Canada (Gotanda, 2003; Bau 2014; Schirripa, 2017). They consist of the award to the victim of a sum of money in addition to what is strictly necessary to compensate the harm suffered. ${ }^{7}$

Under British law, punitive damages contribute, together with compensatory damages, to the achievement of specific objectives, such as punishing the tortfeasor for his behaviour and dissuading market players from engaging in socially harmful behaviours. Moreover, they reward the injured party for enforcing his rights and grant him a further sum of money beyond what is needed to compensate the harm suffered, when the latter appears inadequate 8 (Schirripa, 2017, Croff, 1981, p. 600 et seq.).

Similarly, in the United States, in the event of non-contractual liability 9 (Spoto, 2008, p. 351), courts may impose punitive or exemplary damages in addition to compensatory damages, if the infringer has acted with malice or gross negligence (Cappelletti, 2015, p. 807; Galanter and Luban, 1993, p. 1393, 1397-99). The compensatory function, typical of the remedy for tort law, is therefore accompanied by a punitive and deterrent purpose, which is typical of a penal sanction. Moreover, exemplary damages - according to some of the American legal scholars (Galanter and Luban, 1993, p. 1393, 1397-99;

5 Scotland has a different legal system guaranteed by the Acts of Union of 1707 . This regulation does not provide for punitive damages. See Scottish Law Commission, Report on Damages for Wrongful Death, September 2008: 'Awards of damages are compensatory in nature, not punitive: the aim is to put the victim - or his family - in the position in which he would have been had he not been injured, so far as money can achieve this'.

${ }^{6}$ See The Irish law reform Commission (1998). Consultation paper on aggravated, exemplary and restitutionary damages, p. 59-78, retrieved from: http://www.lawreform.ie/_fileupload/ consultation\%20papers/cpAggravatedDamages.htm. See also Competition Act 2002, Section 14 (5)(b).

7 For alternative definitions of 'punitive damages', see http://www.businessdictionary.com/ definition/punitive-damages.html (they are 'a Court awarded sum that is considerably or greatly higher than the measurable value of the injury. Punitive damages are meant not to compensate the aggrieved party but to punish the offending party for its reckless or unconscionable actions or conduct.'); http://www.dictionary.com/browse/punitive-damages (they are 'damages awarded to a plaintiff in excess of compensatory damages in order to punish the defendant for a reckless or wilful act.').

8 In fact, the author emphasizes that no problem arises when the English courts find themselves having to recognize an American conviction decision that was issued following a judgment in which the injured person acted in a personal capacity, while recognition is excluded when the victim acted as a private public prosecutor (for example, in the antitrust field).

${ }_{9}$ Punitive damages should be recognized only when the reprehensible act committed by the tortfeasor integrates a hypothesis regulated by the law of tort and should not be recognized in the case of breach of contract; however, this principle has undergone many derogations over time. 
Cappelletti, 2015, p. 807) - have also become a tool of public regulation for the prevention of harmful conduct, since a private citizen who has been the victim of, for example, an antitrust violation, can take the position of Private Attorney General and bring his punitive claim against socially unwanted conducts (Rabkin, 1998, p. 196; R.C. Meurkens, 2014, p. 27 et seq. e 189 et seq.; Schirripa, 2017; Iannuccelli, 2015, p. 226).

In the field of US competition law, in particular, there is a special form of compensation with over-compensatory, deterrent and punitive purposes ${ }^{10}$ known as 'treble damages'. ${ }^{11}$ It consists of a sum of money equal to three times the amount of the harm suffered that the judge automatically awards to the injured party. This instrument was introduced to encourage private plaintiffs to enforce antitrust laws ${ }^{12}$ (Cavanagh, 2005, p. 150 et seq. e 169 and et seq.), but it also has the effects of punishing the infringer and discouraging others from engaging in anti-competitive conducts ${ }^{13}$ (Baer, 2014; Wils, 2009, p. 17 et seq.).

In other European countries ${ }^{14}$ (Koziol, 2008, p. 750; Rouhette, 2008, p. 322 et seq.), punitive damages have been, at least initially, regarded by courts as incompatible with national rules on torts and civil liability (Schirripa, 2017; L. Meurkens, 2014, p. 10 et seq.; Saravalle, 1993, p. 875; Borgia, 2008, p. 851 et seq.). In these countries, in fact, damages have an exclusively compensatory function and they seek to indemnify the injured person for the harm suffered through the material restoration of the status quo ante or the payment of an amount of money. The principle on which the damages are based is that of the restitutio in integrum, which consists of re-establishing the same situation

10 There is discussion among legal scholars on the relationship between punitive damages and treble damages. For some of them, they are placed in a genus ad speciem relationship, for others, they exclude each others. On this point, see American Bar Association, Antitrust Section (1998). Punitive Damages and Business Torts, p. 18; William Mitchell Law review (1986). The Antitrust Treble Damages Remedy. William Mitchell Law Review, volume 9, issue 2, Article 9, p. 13. Retrieved from: https://open.mitchellhamline.edu/cgi/viewcontent.cgi?referer=https:// www.google.com $/ \&$ httpsredir $=1 \&$ article $=2632 \&$ context $=$ wmlr $(20.06 .2018)$. It has been stated in the case-law that the application of treble damages excludes that of punitive damages: see the judgement of the US District Court for the Southern District of New York, Hansen Packing Co. v. Armour \& Co., 16 F. Supp. 784, 788, S.D.N.Y., 30 July 1936.

11 Clayton Act, 15 U.S.C.A., paragraph 12 et seq., 1982.

12 William Mitchell Law review (1986). The Antitrust Treble Damages Remedy. Supra.

13 See the judgement of the Supreme Court of the United States Mitsubishi Motors Corp. v. Soler Chrysler-Plymouth, Inc., 473 U.S. 614, 635 (1985), in which it is stated that treble damages create 'a crucial deterrent to potential violators'. See also Directorate for financial and enterprise affairs competition committee (2015). Relationship between public and private antitrust enforcement, p. 2, retrieved from: https://www.ftc.gov/system/files/attachments/ us-submissions-oecd-other-international-competition-fora/publicprivate_united_states.pdf.

${ }^{14}$ Italy, Germany, Austria, Switzerland, Spain, France, Belgium. 
in which the injured party would have been found if a violation had not been committed. Therefore, in a system of this kind, punitive damages are inconceivable because they pursue a different objective, namely deterrence.

In some of these countries, however, there has recently been an attitude of greater openness by national courts, at least with regard to the recognition of foreign rulings that impose punitive damages awards (Zarra, 2016, p. 968; Quarta, 2016, p. 1159B; Lopez De Gonzalo, 2017, p. 714).

In Italy, for example, the Court of Cassation originally took the view that the idea of punishment and sanction was alien to the system of civil liability and claimed that its only function was the restoration of the injured party's property sphere ${ }^{15}$. However, in 2015, the Court of Cassation stated that the sanctioning function of damages is compatible with the general principles of the Italian legal order. In doing so, the Court took into consideration the legislative reforms that have gradually attributed to the compensation system a sanctioning connotation $^{16}$ (Lopez de Gonzalo, 2017, p. 436), alongside the (however preponderant) compensatory-reparatory one. Also the Italian Constitutional Court ruled that civil liability may have both a retributive and compensatory function. ${ }^{17}$ However, the definitive turnaround of Italian jurisprudence took place in 2017, when the Court of Cassation ruled that the concept of punitive damages is not ontologically incompatible with the Italian legal system, provided that the foreign punitive damages award is based on a sufficiently precise provision and complies with the legality and proportionality principles ${ }^{18}$ (Zarra, 2017, p. 722; Lopez De Gonzalo, 2017, p. 714).

Also the French legal system has become gradually less hostile to punitive damages. Indeed, the French Supreme Court overruled a decision of a lower court, which had ruled that punitive damages are incompatible with French public policy. The French Supreme Court ruled that the principles underlying an award of punitive damages are not in themselves contrary to public policy, but that incompatibility may result from the awarded sum of

15 Judgement of the Italian Court of Cassation civ., Sez. III, 19 January 2007, n. 1183; Judgement of the Italian Court of Cassation civ., Sez. I, 8 February 2012, n. 1781.

${ }^{16}$ In this sense, the following have been reputed to indicate the will of the legislator to overcome the traditional reluctance to grant a lato sensu (in a broad sense) punitive character to the compensation: Article 124, paragraph 2 and 131, paragraph 2, of the Legislative Decree n. 30/2005 (which, in the field of patent and trademark, have replaced Articles 86 R.d. 1939/1927 and 66 R.d. 929/1942); Article 140, paragraph 7 of the Legislative Decree n. 206/2005 (on consumer protection); Article 709-ter, n. 1), n. 2) and n. 4), c.p.c. (in the field of non-fulfilment of child custody obligations) and many others.

17 Decision of the Constitutional Court, 11 November 2011, n. 303; decision of the Constitutional Court, June 23, 2016, n. 152.

18 Judgment of the Italian Court of Cassation, United Sections Chambers n. 16601 of 5 July 2017. 
money, if it is disproportionate in relation with the injury suffered and the breach of contractual obligations. Thus, foreign punitive damages awards can in principle be recognised in France unless they are disproportionate to the harm sustained. ${ }^{19}$

The enforcement of punitive damages has also been allowed in a Spanish ruling where the Supreme Court stated that Spanish law does not provide for a strict separation between the civil and the criminal compensation systems: punitive damages, therefore, can be used to make up for the inadequacies of criminal law. ${ }^{20}$

As far as the European Courts are concerned, their positions are divergent: the European Court of Human Rights has consistently rejected, even in cases of serious violations of fundamental rights guaranteed by the ECHR, applicants' requests aimed at obtaining, in addition to material and morals damages, the award of punitive damages. ${ }^{21}$ The Court of Justice of the European Union, on the other hand, established that reparation of harm as a result of breaches of EU law must be commensurate with the harm suffered, but it also stated that national courts may award specific damages, such as exemplary damages, pursuant to claims or actions based on European law, if such damages may be awarded pursuant to similar claims or actions based on domestic law. ${ }^{22}$

With particular regard to competition law, the Court of Justice first confirmed in the Courage judgement the compatibility with EU law of the prohibition of unjust enrichment, which seemed to exclude the possibility for national courts to impose punitive damages. ${ }^{23}$ By contrast, in the subsequent Manfredi ${ }^{24}$ judgment, the Court established the possibility for national courts to increase

19 Judgment of the French Court of Cassation, First Civil Chamber, n. 1090 of 1 December 2010.

20 Judgment of the Spanish Supreme Court, Miller Import Corp. v. Alabastres Alfredo, S.L., of 13 November 2001 (Exequátur No. 2039/1999). However, for some commentators the judgment should be interpreted narrowly and as limited to the specific facts of the case. $C f$. J. De Bruyne, De Potter de Ten Broeck and Van Hiel, 2015, p. 218-221.

21 Judgment of the ECtHR, Akdivar v Turkey, 1 April 1998, n. 21893/93; Judgment of the ECtHR, Selcuk and Askerv Turkey, 24 April 1998, n. 30451/96; Judgment of the ECtHR, Cable and others $v$ United Kingdom, 18 February 1999, n. 24436/94; Judgment of the ECtHR, Gaygusuz v Austria, September 16th 1996, n. 17371/90.

22 Judgment of the European Court of Justice, Case C-46/93 e C-48/93, Brasserie du Pêcheur $S A$ v. Bundesrepublik Deutschland e The Queen v Secretary of State for Transport, ex parte: Factortame Ltd e altri, EU:C:1996:79, para 90.

23 Judgment of the European Court of Justice, Case C-453/99, Courage Ltd v Bernard Crehan e Bernard Crehan v Courage Ltd e altri, EU:C:2001:465, para 30: 'Community law does not prevent national courts from taking steps to ensure that the protection of the rights guaranteed by Community law does not entail the unjust enrichment of those who enjoy them'.

24 Judgment of the European Court of Justice, Joined Cases C-295/04 a C-298/04, Vincenzo Manfredi v Lloyd Adriatico Assicurazioni SpA and others, EU:C:2006:461. 
damages for deterrent purposes, that is, in the absence of a connection with the amount of harm actually suffered by the victim. To this end, in the absence of EU rules governing that field, it is for the domestic legal system of each Member State to set out the criteria for determining the extent of the damages for harm resulting from an antitrust violation, provided that the principles of equivalence and effectiveness are observed. ${ }^{25}$ Therefore, according to the European Court of Justice, 'it must be possible to award particular damages, such as exemplary or punitive damages, pursuant to actions founded on the Community competition rules, if such damages may be awarded pursuant to similar actions founded on domestic law'. ${ }^{26}$

\section{The recoverable damage in Directive 2014/104/EU}

The Damages Directive takes an ambiguous position on the issue of punitive damages: on the one hand, it expresses the intention to follow the case-law of the Court of Justice, on the other hand, it clearly excludes every form of over-compensation in several points.

Recital n. 12, in fact, states that: '[t]his Directive reaffirms the acquis communautaire on the right to compensation for harm caused by infringements of Union competition law, particularly regarding [...] the definition of damage, as stated in the case-law of the Court of Justice'. ${ }^{27}$ The reference to the caselaw of the Court, and in particular to the Manfredi judgment, would therefore allow punitive damages to be admitted in actions based on EU competition rules, at least when they are recognized in similar actions based on domestic law.

Article 3, paragraph 2 goes in the opposite direction providing that the right to full compensation covers the actual loss and the loss of profit, plus the payment of interest, so it does not seem to admit the award of additional amounts by way of punitive damages. ${ }^{28}$ This provision - just like the Communication on the quantification of damage ${ }^{29}$ - in fact, states that 'full compensation shall place a person who has suffered harm in the position in

25 Ibid. paras 92 and 98.

26 Ibid. para 93.

27 Emphasis added.

28 Joined Cases C-295/04 a C-298/04, Manfredi, supra, para 100.

29 Communication from the Commission on quantifying harm in actions for damages based on breaches of Article 101 or 102 of the Treaty on the Functioning of the European Union, OJ C 167, 13.6.2013, p. 19-21, para 6, which says that: 'Compensation for harm suffered means placing the injured parties in the position they would have been in had there been no infringement of Article 101 or 102 TFEU'. 
which that person would have been had the infringement of competition law not been committed'.

Article 3, paragraph 3 has a similar content inasmuch as it categorically excludes the possibility that compensation leads to 'overcompensation, whether by means of punitive, multiple or other types of damages'. This exclusion is reiterated by Recital n. 13 of the Directive: '[w]ithout prejudice to compensation for loss of opportunity, full compensation under this Directive should not lead to overcompensation, whether by means of punitive, multiple or other damages'.

In light of an overall assessment of these hermeneutical elements, it follows that, despite the contradictions, the Damages Directive precludes national courts from awarding punitive damages for the infringement of EU antitrust provisions.

\section{Some considerations on the exclusion of punitive damages from private antitrust enforcement}

In view of the contradictory nature of the content of the Damages Directive, it is not surprising that the course that led to the choice of the exclusion of punitive damages was tortuous and controversial (Vanleenhove, 2012). In fact, the Commission stated in the 2005 Green Paper that, under certain conditions, it would have been appropriate to allow the court to automatically double damages in the case of horizontal cartel infringements. ${ }^{30}$ This proposal arose from the intent to provide for an incentive to the private enforcement of competition law, and it was evidently inspired by the 'treble damages' of US antitrust law. Three years later, in the White Paper, ${ }^{31}$ this proposal disappeared, as the main objective was to improve the conditions for the exercise of the right to compensation for all damages suffered as a result of an infringement of antitrust rules and, therefore, the guiding principle of this document was the idea of complete compensation. ${ }^{32}$ However, in the working document accompanying the White Paper, ${ }^{33}$ the Commission included

30 Green Paper on Damages actions for breach of the EC antitrust rules (SEC(2005) 1732) /COM/2005/0672 final/, para 2.3.

31 White paper on damages actions for breach of the EC antitrust rules (SEC(2008) 404) (SEC(2008) 405) (SEC(2008) 406) /COM/2008/0165 final/.

32 Ibid. para 1.2.

33 Commission staff working paper accompanying the White paper on damages actions for breach of the EC antitrust rules $\{\operatorname{COM}(2008) 165$ final\} \{SEC (2008) 405\} \{SEC (2008) 406\} /*SEC/2008/0404 final*/. 
punitive damages in the acquis communautaire, stating that the Court did not consider them to be contrary to European public order. Therefore, provided that they were awarded in accordance with the general principles of EU law - including fundamental rights - punitive damages based on an infringement of EU competition rules should not be excluded. The Commission also stated that, in accordance with the principle of equivalence, the award of punitive damages should have been possible if it could have been granted on the basis of similar actions based on domestic law and under not less favourable conditions. ${ }^{34}$ However, this approach was ultimately not included in the final text of the Directive.

The European legislator's choice not to provide for any form of overcompensation in this Directive seems to stem from the desire not to deviate from the prevailing legal traditions of the Member States. In fact, as mentioned above, the case-law of many Member States (with the exception of the United Kingdom - Scotland excluded - and the Republic of Ireland) did not recognize punitive damages at first, considering them to be incompatible with systems based on civil liability. The approach changed in some countries only recently, and in any case after the entry into force of the Damages Directive. Bearing witness to what has just been said, the White Paper states that: ' $[\mathrm{t}] \mathrm{he}$ policy choices proposed in this White Paper therefore consist of balanced measures that are rooted in European legal culture and traditions'. ${ }^{35}$ Part of the legal scholarship considered that the above reference to legal traditions was made in order to justify the refusal to introduce punitive damages as an instrument of reaction to damage caused by a violation of competition law rules (Montanari, 2017).

Other authors have advanced the thesis whereby the European legislator would have excluded punitive damages to keep public enforcement clearly separate, entrusted to the European Commission and to the National Competition Authorities, from private enforcement (Pallotta, 2017, p. 624), entrusted to the national judicial authorities, according to the two-track logic (separate-tasks approach) (Wils, 2009, p. 15; Valerini, 2013, p. 231). On the basis of this distribution, public enforcement has the powers of the public authority, while private enforcement must use only the instruments of civil protection, whose function must not be distorted (Iannuccelli, 2015, p. 222; Fonderico, 2015, p. 11). Therefore, according to the proponents of this thesis, the European legislator did not provide for punitive damages in order to avoid entrusting to private enforcement the punitive and deterrent function, which, instead, belongs to public enforcement.

\footnotetext{
34 Ibid., paras 198 and 199.

35 White paper, supra, 3.
} 
There has been much discussion among legal scholars (Barcellona, 2008, p. 120; Bastianon, 2006, p. 321-356; Salomone, 2007, p. 875; Denozza and Toffoletti, 2009, p. 101) on the function that can be carried out by private enforcement. It has emerged, in particular, that damages can perform an exclusively compensatory function or a sanctioning or deterrent function ${ }^{36}$ (Taddei Elmi, 2014, p. 183). In the view of the European legislator, however, obtaining 'full compensation' means only restoring, for anyone who suffered damage, the situation in which it would have been found if the infringement had not been committed, which is equivalent to compensating the actual loss, the loss of profit and the interests. ${ }^{37}$ Therefore, the attention is more focused on the position of the injured party than on the reprehensible conduct of the infringer, and the deterrent effect of the compensation becomes an accessory consequence of an action that has, as its priority, the restoration of the suffered harm. ${ }^{38}$

Overall, the Damages Directive, in line with the legal traditions of the Member States and the two-track logic, has endorsed the view that the quantification of damages serves exclusively a compensatory function ${ }^{39}$ (Bastianon, 2009, p. 140) and it leaves the deterrent function to public enforcement.

${ }^{36}$ Cf. European Group on Tort Law. Principles of European Tort Law. Article 10.101. Retrieved from: http://www.egtl.org (20.06.2018).

37 The legal-economic analysis of the extent of the harm actually suffered by the victim of anti-competitive conduct is very complex. In any case, whatever the parameter (profits, price, costs) chosen to evaluate and quantify the harm suffered, the extent of the harm is always represented by the difference between the situation in which the victim is found after the other illegal behaviour (so-called plaintiff's actual condition) and the situation of the victim in a hypothetical world in which the anti-competitive practice had not been put in place and all other conditions are the same (so-called plaintiff's but-for condition). On this point, see Bastianon, 2006. Cf. Casolari, 2017, p. 4 et seq.; Al Mureden and de Pamphilis, 2017, p. 127 et seq.

38 On the relationship between the deterrent and the compensatory function of compensation for damages, see Denozza and Toffoletti, 2009, p. 104-105, 117.

$39 C f$. White paper, supra, that affirms that: 'The primary objective of this White Paper is to improve the legal conditions for victims to exercise their right under the Treaty to reparation of all damage suffered as a result of a breach of the EC antitrust rules. Full compensation is, therefore, the first and foremost guiding principle'. Moreover: 'Improving compensatory justice would therefore inherently also produce beneficial effects in terms of deterrence of future infringements and greater compliance with EC antitrust rules' (para 1.2). 


\section{On the advisability of providing for punitive damages in private antitrust enforcement. A possible solution}

Public enforcement ensures a certain level of protection for individuals. However, this protection could be significantly more intense if the Directive would provide for the possibility for national courts to award punitive damages, if necessary. In fact, in the context of competition, compensating only the harm suffered by the victim could not make the infringer lose the profits from the infringement, thus encouraging the latter to repeat the prohibited conduct. This danger could be averted with the recognition of further punitive compensation.

In this regard, it has been noted that this solution may have some contraindications (Cavanagh, 2005, p. 171; Buccirossi, Ciari, Duso, Spagnolo and Vitale, 2009). Indeed, on the one hand, it is true that forms of punitive damages, such as the US 'treble damages', may be appropriate in terms of deterrence in the case of concealed illegal behaviours (for example, price fixing, division of markets and collective boycotts), given the reasonable probability that the conduct will not be discovered and therefore punished. On the other, it is also true that punitive damages can create problems of excessive deterrence (so-called 'overdeterrence') in cases of not concealed illegal conducts (for example, tying or monopolistic overcharges), with the damaging consequence that pro-competitive, and therefore legal, behaviours could be discouraged for fear of being condemned to the payment of considerable amounts as damages. The appropriate level of deterrence, according to these legal scholars, should be determined on the basis of the likelihood that the unlawful conduct will be discovered, but this is very difficult to establish (Cavanagh, 2005, p. 171).

Therefore, in order to avoid problems of unjustified over-compensation and overdeterrence that may derive from the award by the court of a compensation corresponding to a fixed amount, that does not depend on the type of illegal conduct undertaken (as in the case of 'treble damages'), the Damages Directive should allow the court to make a case-by-case assessment. Following this assessment, the court should be allowed - preferably on the basis of an economic legal analysis - to impose (either of its own motion or at the request of the plaintiff) the payment of a further amount of money in addition to that strictly necessary to compensate the harm suffered, that makes the infringer lose all the profits from the infringement and that has a deterrent effect, dissuading market players from engaging in similar anti-competitive conducts in the future.

Indeed, if on the one hand it is true that damages are intended primarily to perform a compensatory function, and that the field reserved to public 
enforcement must not be invaded, it is true on the other hand that the deterrent function of damages cannot be neglected and so it should be elevated to a goal, albeit a secondary one, of the system of private antitrust enforcement.

A further reason to support this thesis lies in the fact that public competition authorities may not always be able to ascertain and punish anti-competitive conducts. The investigation activity and the pursuit of such conducts sometimes involve very high costs. ${ }^{40}$ Thus, the gap in the deterrent function of public enforcement could be closed with private enforcement through the provision of punitive damages.

Therefore, the division of functions between private and public enforcement should be structured as follows: the function of preventing and deterring market players from anti-competitive behaviours should be shared between public and private enforcement ${ }^{41}$ (Denozza and Toffoletti, p. 119-120); compensation for damages suffered by victims of anti-competitive behaviours should be provided via private enforcement through compensation for damages; the punitive function should, instead, remain a matter of public enforcement. ${ }^{42}$ In such a system, the possible recognition of punitive compensation operated by national courts would support both the preventive and deterrent function of private enforcement as well as its compensatory role. This solution is inspired by what has been defined by legal scholars as the 'deterrence approach' (Wils, 2009, p. 17.), as opposed to the 'separate tasks approach' adopted by the European legislator first in the White Paper and then in the Damages Directive.

The proposed solution, namely that of giving the court the discretion in quantifying the damage, so as to adapt it to the present case and to create a sufficient deterrent effect for the future, would also favour greater consistency with other acts of the European legislator. Directive 2004/48/EC ${ }^{43}$ on the

40 In fact, some American legal scholars claim that the US federal lawmaker created private enforcement to integrate public enforcement, for fear that the government did not have the necessary resources to discover, investigate and prosecute all violations of antitrust laws. On this point, $C f$. Cavanagh, 2005, p. 152-153; L. Meurkens, 2014, p. 26.

41 The authors emphasize that the complementarity of private and public actions resides in the fact that they produce different qualities of deterrence.

42 There are some legal scholars that propose a third system in addition to public and private enforcement: public compensation. This system would give public authorities the task of modulating the sanction taking into account compensatory requirements, then transferring the wealth obtained from the convicted companies to damaged parties, when it is possible to identify them, or to exponential entities operating on the market damaged by the cartel. On this point, see Ezrachi, Ioannidou, 2012, p. 132; Iannuccelli, 2015, p. 222.

43 Corrigendum to Directive 2004/48/EC of the European Parliament and of the Council of 29 April 2004 on the enforcement of intellectual property rights (OJ L 157, 30.4.2004), OJ L 195, 2.6.2004, p. 16-25. 
enforcement of intellectual property rights, for example, explicitly allows national judicial authorities to provide for 'punitive' compensation. ${ }^{44}$ This rule was interpreted by the Court of Justice, which stated that Directive 2004/48/EC 'does not have the aim of introducing an obligation to provide for punitive damages' 45 but at the same time it 'cannot be interpreted as a prohibition on introducing such a measure'. ${ }^{46}$ This judgement is part of the jurisprudential line of the Court of Justice which some legal scholars defined as 'possibilist' with respect to the admissibility of compensatory remedies of a not-strictlycompensatory nature (Busnelli, 2009, p. 920), a line which also includes the aforementioned Manfredi ruling and the Brasserie de Pêcheur judgment. ${ }^{47}$

Moreover, in the Report on the application of the Directive 2004/48/EC, 48 the Commission says that when damages awarded by the courts fail to match the level of profit made by the infringers, they do not currently appear to effectively dissuade potential infringers from engaging in illegal activities. Therefore, in such cases, it could be considered whether the courts should have the power to grant damages commensurate with the infringer's unjust enrichment, even if they exceed the actual damage incurred by the right holder (Connor and Lande, 2007, p. 2-4).

In light of the above, it is difficult to understand why the violation of competition law gives rise to less stringent remedies than those envisaged for the violation of intellectual property rights. The European legislation should offer a minimum standard of protection, leaving the possibility to the

${ }_{44}$ Article 13, paragraph 1 of Directive 2004/48/EC, in fact, states that: 'When the judicial authorities set the damages: (a) they shall take into account all appropriate aspects, such as the negative economic consequences, including lost profits, which the injured party has suffered, any unfair profits made by the infringer and, in appropriate cases, elements other than economic factors, such as the moral prejudice caused to the rightholder by the infringement; or (b) as an alternative to (a), they may, in appropriate cases, set the damages as a lump sum on the basis of elements such as at least the amount of royalties or fees which would have been due if the infringer had requested authorisation to use the intellectual property right in question'.

45 Judgement of the European Court of Justice, case C-367/15, Stowarzyszenie Otawska Telewizja Kablowa, EU:C:2017:36, para 27.

46 Ibid., para 28.

47 Judgement of the European Court of Justice, reunited case C-46/93 e C-48/93, Brasserie du Pêcheur, supra, related to a case of liability of a Member State for an infringement of European law. The Court affirmed that the compensation for exemplary damages, based on the 'finding that the public authorities concerned acted oppressively, arbitrarily or unconstitutionally' may, if that conduct constitutes or aggravates a breach of Community law, be recognised if such damages could be awarded pursuant to a similar claim or action founded on domestic law' (para 89).

48 Report from the Commission to the European Parliament, the Council, the European Economic and Social Committee and the Committee of the Regions application of Directive 2004/48/EC of the European Parliament and the Council of 29 April 2004 on the enforcement of intellectual property rights /com/2010/0779 final /. 
legislations of the Member States to provide for more stringent remedies against the infringer. Moreover, it should not impose a ceiling, which is indeed very stringent, on national remedies.

Overall, in Directive 2014/104/EU it was advisable to adopt a less rigid solution, of greater openness to the possibility of referring to national courts the choice to provide for punitive damages or, at least, to quantify the harm in such a way as to fully protect victims of anti-competitive practices, and to discourage the recurrence of wrongdoings.

\section{Conclusion}

With the Damages Directive there has been a significant change in the approach to the concept of punitive damages in Europe. As seen above, in fact, the initial hostile attitude of the European courts towards this concept has gradually turned into acceptance, at least in the context of the recognition of foreign decisions. This also happened in the wake of Court of Justice rulings, which stated that a particular form of damages, that is, exemplary or punitive damages, could be awarded in actions based on European competition rules if it may be awarded in similar actions based on domestic law. By contrast, with the Damages Directive the European legislator has reversed the course, ruling out every form of over-compensation in the context of private antitrust enforcement.

This choice, as previously stated, is objectionable for various reasons. First of all, because it is at odds with the previous case-law of the Court of Justice and with the rules on compensation laid down in Directive 2004/48/EC, thus giving rise to an inexplicable inequality between victims of anti-competitive conduct and victims of intellectual property rights infringements. Secondly, because private antitrust enforcement should ensure an effective compensation of the harm suffered, and it should ensure that the infringers forfeit all the profits obtained from their anti-competitive conduct. Third, because private antitrust enforcement should also perform a deterrent function so as to discourage future anti-competitive conduct. Arguably, without punitive damages, private enforcement for the infringement of EU antitrust law boils down to an incomplete, half-baked solution.

Therefore, it is submitted that the Commission should radically rethink the rule contained in Article 3, paragraph 3 of the Damages Directive in the context of the review that the Commission is required to make, in accordance with Article 20 of the Directive, for the presentation of a report to the European Parliament and to the Council by 27 December 2020. 
In particular, the new version of Article 3, paragraph 3 of the Directive should arguably enable national courts to award punitive damages, or at least leave them additional discretion in quantifying anti-competitive harm, so as to enable damage awards to completely offset the profits obtained by the antitrust infringers. In any case, the new provision should enable national courts to award damages on the basis of the peculiar feature of each case, preferably on the basis of an economic legal analysis. This discretion would also avoid the problem of unjustified over-compensation and of overdeterrence that arises when courts are required to recognize a fixed amount as punitive compensation (as in the case of 'treble damages'), since courts would have a certain margin of discretion in deciding the sum to be awarded in the light of the type of unlawful conduct committed and the circumstances of the case. Under these conditions, antitrust damages would be an effective tool to fully protect the victims of anti-competitive conduct, and to deprive antitrust infringers of all the profits that they had obtained. Finally, damage awards could yield an important deterrent effect, discouraging future anti-competitive conduct by the infringer and by other market players.

\section{Literature}

Al Mureden, E. and De Pamphilis, M. (2017). Valutazione dei danni. In: P. Manzini (ed.), Il risarcimento del danno per violazioni del diritto della concorrenza. Commento al d.lgs. n. 3/2017 (pp. 126-157). Turin: Giappichelli Editore.

American Bar Association, Antitrust Section (1986). Treble-Damages Remedy. Monograph n. $13,18$.

Baer, B. (2014). Public and Private Antitrust Enforcement in the United States. Retrieved from: https://www.justice.gov/atr/file/517756/download (20.06.2018).

Barcellona, M. (2008). Funzione compensativa della responsabilità e private enforcement della disciplina antitrust. Contratto e impresa 1 (p. 120). Retrieved from: http://www. iusimpresa.com/risultati.php?hdd_lg $=\&$ hdd_mono $=16099 \&$ hdd_autore $=38930 \&$ hdd_ ricerca $=\mathrm{RB}(20.06 .2018)$.

Bastianon, S. (2009). I costi delle azioni risarcitorie antitrust. In: F.R. Dal Pozzo and B. Nascimbene (eds), Il private enforcement delle norme sulla concorrenza (pp. 137-150). Milan: Giuffrè Editore.

Bastianon, S. (2006). Il risarcimento del danno antitrust tra esigenze di giustizia e problemi di efficienza. Prime riflessioni sul Libro verde della Commissione. Mercato Concorrenza Regole 2, 322.

Bau, L. (2014). The History and Treatment of Damages in Canada. Retrieved from: https:// www.lindsayllp.ca/the-history-and-treatment-of-damages-in-canada/ (20.06.2018).

Borgia, F. (2008). Sentenza straniera di condanna a danni punitivi e ordine pubblico. In: Studi in onore di Umberto Leanza (pp. 851 et seq.). Naples: Editoriale Scientifica. 
Buccirossi, P., Ciari, L., Duso, T., Spagnolo, G. and Vitale, C. (2009). Deterrence in competition law, Governance and the efficiency of economic system. Working Paper n. 285. Retrieved from: https://pdfs.semanticscholar.org/b7bd/197aeb3863247b307aba 98225d60a0c5e312.pdf (20.06.2018).

Busnelli, F.D. (2009). Deterrenza, responsabilità civile, fatto illecito, danni punitivi. In: Europa e diritto privato, issue 4, 934 et seq.

Cappelletti, M. (2015). Punitive Damages and the Public/Private Distinction: A Comparison Between the United States and Italy. Retrieved from: http://nrs.harvard.edu/urn-3:HUL. InstRepos:25818261 (20.06.2018).

Casolari, F. (2017). Diritto ad un pieno risarcimento. In: P. Manzini (ed.), Il risarcimento del danno per violazioni del diritto della concorrenza. Commento al d.lgs. n. 3/2017 (pp. 1-14). Turin: Giappichelli Editore.

Cavanagh, E.D. (2005). Antitrust Remedies Revisited. Oregon Law Review 84(1). Retrieved from: https://scholarsbank.uoregon.edu/xmlui/handle/1794/4643 (20.06.2018).

Lande, R.H. and Connor, J.M. (2007). Cartel Overcharges and Optimal Cartel Fines. Retrieved from: https://ssrn.com/abstract=1029755 (20.06.2018).

Croff, C. (1981). La prassi giudiziaria statunitense antitrust e il Protection of interests Trading Act del Regno Unito. Rivista di Diritto Internazionale, 600 et seq.

De Bruyne, J., De Potter de Ten Broeck, M. and Van Hiel, I. (eds). (2015). Policy within and through law: proceedings of the 2014 ACCA-conference. Antwerpen - Apeldoorn Portland: Maklu.

Denozza, F. and Toffoletti, L. (2009). Le funzioni delle azioni private nel Libro Bianco sul risarcimento del danno antitrust: compensazione, deterrenza e coordinamento con l'azione pubblica. In: F. Rossi Dal Pozzo and B. Nascimbene (eds), Il private enforcement delle norme sulla concorrenza (pp. 101-122). Milan.: Giuffrè Editore.

Directorate for financial and enterprise affairs competition committee (2015). Relationship between public and private antitrust enforcement. Retrieved from: https:/www.ftc.gov/ system/files/attachments/us-submissions-oecd-other-international-competition-fora/ publicprivate_united_states.pdf (20.06.2018).

European Commission. Report from the Commission to the European Parliament, the Council, the European Economic and Social Committee and the Committee of the Regions application of Directive 2004/48/EC of the European Parliament and the Council of 29 April 2004 on the enforcement of intellectual property rights / com/2010/0779 final/. Retrieved from: https:/eur-lex.europa.eu/legal-content/EN/ TXT/?uri=CELEX\%3A52010DC0779 (20.06.2018).

European Group on Tort Law. Principles of European Tort Law. Article 10.101. Retrieved from: http://www.egtl.org (20.06.2018).

Ezrachi, A. and Ioannidou, M. (2012). Public compensation as a Complementary Mechanism to Damages Actions: From Policy Justifications to Formal Implementation. Journal of European Competition Law and Practice 6, 536.

Fonderico, G. (2015). Private e Public enforcement. Annali Italiani del diritto d'autore, della cultura e dello spettacolo XXIV, 3-14.

Fulton, J. (2017). Litigation and enforcement in the UK (Scotland): overview. Retrieved from: https://uk.practicallaw.thomsonreuters.com/8-593-3006?transitionType $=$ Default $\&$ contextData $=($ sc. $)(20.06 .2018)$.

Galanter, M. and Luban, D. (1993). Poetic Justice: Punitive Damages and Legal Pluralism. American University Law Review 42, 1394-1462. 
Gotanda, J.Y. (2003). Punitive Damages: A Comparative Analysis. Retrieved from: https:// digitalcommons.law.villanova.edu/wps/art8/ (20.06.2018).

Iannuccelli, P. (2015). La responsabilità delle imprese nel diritto della concorrenza dell'Unione europea e la Direttiva 2014/104. Milan: Giuffrè Editore.

Koziol, H. (2008). Punitive Damages - A European Perspective. Louisiana Law Review 68(3). Retrieved from: https://digitalcommons.law.lsu.edu/cgi/viewcontent.cgi?referer $=$ https:// www.google.com $/ \&$ httpsredir $=1 \&$ article $=6240 \&$ context $=$ lalrev $(20.06 .2018)$.

Lopez De Gonzalo M. (2017). La Corte di Cassazione cambia orientamento sui punitive damages. Diritto del Commercio Internazionale 3, 714-721.

Lopez de Gonzalo, M. (2017). Proprietà intellettuale e danni punitivi di fronte alla Corte di giustizia europea. Diritto del Commercio Internazionale 2, 435-454.

Meurkens, L. (2014). The punitive damages debate in continental Europe: food for thought. Retrieved from: http://www.ssrn.com (20.06.2018).

Meurkens, R.C. (2014). Punitive Damages - The Civil Remedy in American Law, Lessons and Caveats for Continental Europe. Wolters Kluwer Business. Retrieved from: https:// cris.maastrichtuniversity.nl/portal/en/publications/punitive-damages-the-civil-remedyin-american-law-lessons-and-caveats-for-continental-europe(c4e5feeb-ad60-43d3-b0d267c794d312f3).html (20.06.2018).

Montanari, A. (2017). La resistibile ascesa del risarcimento punitivo nell'ordinamento italiano (a proposito dell'ordinanza n. 9978/2016 della Corte di Cassazione). Diritto civile contemporaneo. Retrieved from: http://dirittocivilecontemporaneo.com/2017/02/ la-resistibile-ascesa-del-risarcimento-punitivo-nellordinamento-italiano-a-propositodellordinanza-n-99782016-della-corte-di-cassazione/ (20.06.2018).

Pallotta, O. (2017). Public e private antitrust enforcement alla luce della direttiva 2014/104/ UE: l'equilibrio alterato. Studi sull'integrazione europea 3, 621-640.

Quarta, F. (2016). Illecito civile, danni puntivi e ordine pubblico. Responsabilità Civile e Previdenza 4, 1159-1172.

Rabkin, J.A. (1998). The secret life of the Private Attorney General. Law and Contemporary Problems 61(1). Retrieved from: https://pdfs.semanticscholar.org/754b/8d7dadbf5160db 25a61e1a9a8c15aaade3a6.pdf (20.06.2018).

Rouhette, T. (2008). The availability of punitive damages in Europe: growing trend or nonexistent concept? Defense Counsel Journal 74(4), 320-340.

Salomone, E. (2007). Il risarcimento del danno da illeciti antitrust: profili di tutela interna e comunitaria. Rivista trimestrale diritto processuale civile 61(3), 875-902.

Saravalle, A. (1993). I punitive damages nelle sentenze delle corti europee e dei tribunali arbitrali. Rivista di diritto internazionale privato e processuale, 875.

Schirripa, M. (2017). I danni punitivi nel panorama internazionale e nella situazione italiana: verso il loro riconoscimento?. Retrieved from: www.comparazionedirittocivile. it (20.06.2018).

Scottish Law Commission (2008). Report on Damages for Wrongful Death.

Spoto, G. (2008). I danni punitivi e il risarcimento del danno ambientale. In: F. Alcaro et al. (eds), Valori della persona e modelli di tutela contro i rischi ambientali e genotossici. Florence: Firenze University Press.

Taddei Elmi, G. (2014). Il risarcimento dei Danni antitrust tra compensazione e deterrenza. Il modello Americano e la proposta di direttiva UE del 2013. Concorrenza e Mercato 1, 183-234. 
The law reform commission (1998). Consultation paper on aggravated, exemplary and restitutionary damages. Retrieved from: http://www.lawreform.ie/_fileupload/ consultation\%20papers/cpAggravatedDamages.htm (20.06.2018).

Todino, M. (2015). Il danno risarcibile. Annali italiani del diritto d'autore, della cultura e dello spettacolo XXIV, 15-31.

Valerini, F. (2013). Il giudizio di merito nell'azione antitrust. In: L.F. Pace (ed.), Dizionario sistematico del diritto della concorrenza (pp. 231-246). Retrieved from: http://www. competition-law.eu/wp-content/uploads/2014/04/Dizionario-completo.pdf (20.06.2018).

Vanleenhove, C. (2012). Punitive damages and European Law, quo vademus?. Retrieved from: https://papers.ssrn.com/sol3/papers.cfm?abstract_id=2054595 (20.06.2018).

William Mitchell Law Review (1986). The Antitrust Treble Damages Remedy. William Mitchell Law Review 9(2), Article 9, p. 13. Retrieved from: https://open.mitchellhamline. edu/cgi/viewcontent.cgi?referer=https://www.google.com/\&httpsredir $=1 \&$ article $=2632$ \&context $=$ wmlr $(20.06 .2018)$.

Wils, W.P.J. (2009). The Relationship between Public Antitrust Enforcement and Private Actions for Damages. World Competition 32(1), 3-26.

Zarra, G. (2016). The doctrine of punitive damages and international arbitration. Diritto del Commercio internazionale 4, 963-991.

Zarra G. (2017). Lordine pubblico attraverso la lente del giudice di legittimità: in margine a Sezioni Unite 16601/17. Diritto del Commercio Internazionale 3, 722-749. 